\title{
“OPINIÕES”: CRÍTICAS SOBRE AS ARTES PLÁSTICAS NO BRASIL (1965-1968)
}

\author{
“Opinions”: criticisms about plastic arts in Brazil (1965-1968)
}

Valéria Aparecida Alves*

\begin{abstract}
RESUMO: O texto ora proposto, visa discutir a narrativa propagada na imprensa sobre experiências estéticas nas artes plásticas, no período de 1965-1968, especificamente, com relação às exposições: "Opinião 65", "Opinião 66", "Nova Objetividade Brasileira" (1967) e "IV Salão de Arte Moderna de Brasília" (1967-1968). Analiso o debate estabelecido, a partir dos textos dos críticos de arte: Harry Laus (Jornal do Brasi), Mário Pedrosa (Correio da Manhã) e Frederico de Morais (Diário de Notícias).
\end{abstract}

Palavras-chave: Artes Plásticas. "Opinião 65". "Opinião 66”. "Nova Objetividade Brasileira" (1967). IV Salão de Arte Moderna de Brasília (1967-1968).

ABSTRACT: The text aims to discuss the press discourse about aesthetic experiences in the plastic arts, between 1965-1968. It specifically investigates four exhibitions - "Opinion 65", "Opinion 66", "New Brazilian Objectivity" (1967) and "IV Modern Art Exhibition in Brasília" (1967-1968) - and their repercussions in national newspapers analyzing published texts by the fowling art critics: Harry Laus (Jornal do Brasil), Mário Pedrosa (Correio da Manhã) and Frederico de Morais (Diário de Notícias).

Keywords: Plastic Arts. "Opinion 65". "Opinion 66". New Brazilian Objectivity" (1967). IV Modern Art Exhibition in Brasilia (1967-1968).

\section{Considerações iniciais}

A década de 1960 foi marcada por inúmeras mudanças, nos planos político, econômico, cultural e social (costumes). No campo das artes, verifica-se a multiplicidade de tendências: a pop art, o nowveau réalisme, a arte povera, a op art, entre outras. O período foi caracterizado por uma relação interdisciplinar, o cotidiano (particular) como temática, uso e fusão de materiais (sacos, malas, caixas, tecidos, plástico, aço) e do corpo para a criação. Momento de rupturas e diálogo internacional. Tempo em que os artistas começam a produzir fora dos ateliers e galerias e intencionam transformar o público - até então considerado mero espectador - em participante. A arte passava a ser, sobretudo, sensorial e exigia do público, o uso de todos sentidos, não bastava mais apenas contemplar, era preciso intervir, recriar, atribuir sentido, pois era o momento da obra de arte "aberta", ou seja, o artista propõe e o público/participante interfere e também, significa a obra. Reivindicava-se a

\footnotetext{
* Doutora em História Social pela Pontifícia Universidade Católica (2011), com Mestrado em História pela Pontifícia Universidade Católica de São Paulo (2001) e Graduação em História pela Universidade Cidade de São Paulo (1994). Atualmente é Professora Adjunta da Universidade Estadual do Ceará - UECE, atuando principalmente nos seguintes temas: Ditadura Militar, Produção cultural nas décadas de 1960 e 1970 e Movimentos de Contracultura. Vinculada ao Grupo de Pesquisa - Laboratório de Estudos e Pesquisa em História e Culturas - DÍCTIS, especificamente à linha de pesquisa: Música, musicalidade e experiências ético-estéticas. E-mail: valeria.alves@uece.br
} 
liberdade experimental e questionava-se o estatuto da arte.

No Brasil, tal discussão foi ampliada durante a década de 1960, em meio à vigência do estado autoritário ${ }^{1}$, implementado pelo golpe civil-militar de 31 de março de 1964, e às questões sobre as diversas formas de resistência no campo das artes. Na luta pela redemocratização do país, vários intelectuais e artistas se engajaram e, consequentemente, as questões sobre a importância da arte e, seus limites e alcance, mobilizaram várias discussões, que repercutiram na imprensa, possibilitando a reflexão sobre as experiências estéticas nas artes plásticas do período.

A partir de diferentes proposições, nota-se, contudo, um aspecto comum: a defesa da liberdade para a criação artística, o questionamento de "fórmulas", ou seja, a busca do rompimento com as convenções artísticas e, sobretudo, a tentativa de ampliar o acesso às artes - em especial as artes plásticas - e o diálogo mais próximo e direto com o público.

Conforme acima afirmado, o presente texto discute as experiências estéticas nas artes plásticas, no período de 1965-1968 - especificamente, a partir das exposições: "Opinião 65", "Opinião 66", "Nova Objetividade Brasileira” (1967) e IV Salão de Arte Moderna de Brasília (1967-1968). Analiso o debate estabelecido, repercutido na imprensa, a partir dos textos críticos de arte: Frederico de Morais (Jornal Diário de Notícias), Harry Laus (Jornal do Brasil) e Mário Pedrosa (Jornal Correio da Manhã).

\section{A crítica de arte}

A década de 1960 foi marcada pelo uso dos espaços públicos - praças, parques e ruas para manifestações de diversos setores da sociedade, em especial do movimento estudantil, e, também, para a produção coletiva das experiências estéticas, inclusive, nas artes plásticas, considerada uma das manifestações artísticas mais elitistas. $\mathrm{O}$ artista buscava deixar seu atelier para a criação artística, em contato direto com o público, tornando-o coprodutor da obra. A relação arte e política pautava as discussões e sinalizavam novos caminhos que transformariam a realidade brasileira. "Os anos 60 e 70 assistem ao nascimento e organização de uma geração artística que pregava a formulação de uma nova concepção de arte, a qual reivindicava a assimilação crítica da cultura brasileira" (CAVALCANTI, 2005, p. 41). E, sobre o contexto das artes plásticas no Brasil dos anos 1960, afirmou-se que:

\footnotetext{
${ }^{1}$ A Ditadura Militar no Brasil vigorou de 1964 a 1985. No período, cinco generais revezaram-se na Presidência da República, sendo: Humberto de Alencar Castelo Branco (1964-1967), Artur da Costa e Silva (19671969), Emílio Garrastazu Médici (1969-1974), Ernesto Geisel (1974-1979) e João Batista Figueiredo (1979-1985). As medidas de cerceamento das liberdades e repressão aos movimentos de oposição foram, gradualmente, adotadas entre os anos de 1964 e 1968, com a edição dos Atos Institucionais, sendo que o Al-5, editado em 13 de dezembro de 1968, promoveu a suspensão dos direitos e garantias individuais e a suspensão do habeas corpus, resultando no período denominado "anos de chumbo" (1969-1974), com o aumento significativo de prisões, práticas de torturas e exílios. A partir de 1974, iniciou-se o período de abertura política "Ienta, gradual e segura", conforme anunciou o general-presidente Ernesto Geisel e em meio a grave crise econômica, vivida desde 1973. o processo de abertura foi concluído em 1985, após a realização de eleição indireta para a Presidência da República, que deu início ao período de redemocratização do país. Sobre o período consultar: REIS, Daniel Aarão. (Coord.) Modernização, ditadura e democracia: 1964-2010. Rio de Janeiro: Objetiva, 2014 (História do Brasil Nação: 1808-2010; v.4); MOREIRA, Maria Helena Alves. Estado e Oposição no Brasil (1964-1984). Bauru, SP: EDUSC, 2005; REIS, Daniel Aarão, RIDENTI, Marcelo, MOTTA, Rodrigo Patto Sá. (Orgs.) A ditadura que mudou o Brasil: 50 anos do golpe de 1964. Rio de Janeiro: Zahar, 2014; REIS, Daniel Aarão. Ditadura e Democracia no Brasil. Rio de Janeiro: Zahar, 2014; SCHWARCZ, Lilia Moritz. Sobre o autoritarismo brasileiro. São Paulo: Companhia das Letras, 2019 e SCHWARCZ, Lilia Moritz e STARLING, Heloisa Murgel. Brasil: uma biografia. São Paulo: Companhia das Letras, 2015.
} 
[...] Gêneros milenares como a pintura e a escultura são repensados, questionados e, em alguns casos, literalmente execrados. A colagem cubista, o ready-made e as merz dadaístas são teologicamente resgatados e fundidos aos novos meios e conceitos, ao corpo, ao processo e ao tempo, numa intensa sucessão de "ismos". A explosão das linguagens e suportes é um fato internacional nessa década [...] Entre 1964 e 1968, nas diversas áreas da produção cultural brasileira como se disse - há um adensamento crítico da oposição e o recrudescimento de uma espécie de arte de contestação - em detrimento do poder repressivo do regime autoritário (FREITAS, 2004, p. 60 e 82).

Foi neste contexto que, entre 12 de agosto e 12 de setembro de 1965, o MAM - RJ, inaugurou quatro exposições que integravam a programação das comemorações do IV Centenário da cidade do Rio de Janeiro, das quais sobressaiu a "Opinião 65", com ampla repercussão na imprensa, que já antecipava as proposições estéticas inovadoras que se relacionavam à arte sensorial, como a criação de Hélio Oiticica:

[...] As quatro exposições foram abertas ao público às 13 horas e mais de mil pessoas percorreram todas as galerias, ficando a grande maioria à saída, sem saber do que mais havia gostado. Um grupo de passistas da Mangueira levou ao MAM a música proveniente da obra de Hélio Oiticica - Parangolé - formada por panos, plásticos, esteiras, telas, cordas, que ninguém saiba explicar, mas que o artista chamava de arte ambiental por excelência (Jornal do Brasil, 13 de agosto de $1965-1^{\circ}$ Caderno, p.14).

[...] Opinião 65 é uma interessante e discutida mostra que reúne 16 pintores brasileiros e 12 estrangeiros ${ }^{3}$. Afirmam ser esta mostra uma exposição de ruptura. "Ruptura com a arte do passado". Vejam-na porque, em breve, comentaremos o assunto. (BARBOSA, Sylvia. ARTES PLÁSTICAS - Novas Exposições no MAM - Jornal Diário de Notícias, 15 de agosto de 1965 - Suplemento Literário, p. 7).

Sobre a exposição, o crítico Mário Pedrosa (1900-1981), comparava o evento no Brasil e em França, e salientava a criação das proposições estéticas inovadoras e experimentais. O crítico ressaltava o caráter de vanguarda do evento, afirmando que:

[...] No mundo, em geral, mas pelos centros culturais periféricos em particular, as grandes manifestações públicas coletivas de arte raramente são contemporâneas. Ou melhor, são "Opiniões" do ano. "Opinião" do ano é "o salão de automóvel", como por exemplo, o de Paris. Por quê? Porque este é diretamente organizado e dirigido para o mercado consumidor. Daí seu teor realmente up to date. É o último môdelo. Nas manifestações da arte de nossos dias o movimento espontâneo, deixado a si mesmo, sem os atropelamentos, fricções e resistências dos próprios artistas, dos próprios criadores, iria àquela perfeição do salão do automóvel, por sinal, inaugurador em Paris da "temporada das artes" do ano, que começa como as aulas ao fim do verão [...] (PEDROSA, Mário. Opinião ... Opinião ... Opinião. Jornal Correio da Manhã, 11 de setembro de $1966,4^{\circ}$ Caderno, p.3 - grifos originais do texto).

2 [...] "Participaram da exposição os europeus: Vanarsky, Genovés, Adzak, Berni (argentino), Foldes, Tisserand, Gaïtis, Macréau, Jardiel, Bertini, Jacquet, Chistoforou, além dos brasileiros: Aguilar, Antônio Dias, Escostéguy, Angelo de Aquino, Waldemar Cordeiro, Roberto Magalhães, Vergara, Hélio Oiticica, D’Aquino, Gerchman, Juan Freitas, Serpa, Flávio Império, Gastão Manuel Henrique, Tomoshigue e Wilma Pasqualini" (AMARAL, 1984, p. 330-331).

3 [...] "Foram 13 artistas franceses e estrangeiros e 17 brasileiros, entre eles Adriano e Ângelo de Aquino, Carlos Vergara, Antônio Dias, Hélio Oiticica, Ivan Freitas, Ivan Serpa, José Roberto Aguilar, Pedro Escotesguy, Roberto Magalhães, Rubens Gerchman, Waldemar Cordeiro, Wesley Duke Lee, Manuel Calvo, José Paredes Jardiel, Juan Genovés, Alain Jacquet, Peter Foldes e Antônio Berni. Vilma Pasqualini era a única mulher" (PALMEIRA, 2015, p. 284). 
Mário Pedrosa, reconhecia ainda, que a exposição “Opinião 65”, cumpria um papel importante e oportuno, em meio ao contexto autoritário vivido no Brasil, do qual era opositor ferrenho ${ }^{4}$. Exaltava, também, o "diálogo" entre as expressões artísticas - o teatro e artes plásticas -, observado na organização do evento:

[...] Houve aqui pequena mostra no ano passado que apareceu, sob a feliz iniciativa de Ceres Franco e Jean Boghici, com o título enormemente sugestivo de Opinião 1965. A idéia foi um achado naquele instante. Por quê? Porque se inspirava no teatro, no teatro popular tão próximo, por sua própria natureza, ao clima social, à atmosfera política da época. Pode-se dizer que o grupo do Teatro da Arena, com sua Opinião 65, foi o grande respiradouro dos cidadãos abafados pelo clima de terror e de opressão cultural do regime militar implantado em 1964 e definido moral, política e culturalmente pelas incursões de uma entidade anônima e irresponsável dita linha dura [...] (PEDROSA, Mário. Opinião ... Opinião ... Opinião. Jornal Correio da Manhã, 11 de setembro de $1966,4^{\circ}$ Caderno, p. 3 - grifos originais do texto).

Contudo, se Mário Pedrosa, exaltava entusiasticamente a exposição, apresentando-a como um movimento de ruptura nas artes, outro importante crítico de arte e artista (poeta), Ferreira Gullar, faria reservas ao evento, sem tirar o mérito da atividade. Ponderava que, a exposição não marcava a "ruptura" no campo das artes plásticas, pois, o movimento de mudança era anterior. De acordo com Gullar, o mérito da exposição estava na aproximação dos artistas com a realidade social, questão defendida por ele, conforme argumentou:

[.... "Tomemos o cuidado de não atribuir a essa pequena exposição, que reúne vinte e nove artistas e um punhado de obras, o mérito de marcar, agora, uma mudança histórica na pintura", o destacável, no fato, reside, na verdade, em que os artistas "descobriram também que, do outro lado, na vida de todo dia, havia muita coisa, para não dizer tudo". Esse é o ponto a destacar na mostra, o "interesse pelas coisas do mundo, pelos problemas do homem, da sociedade em que vivem. E daí a possibilidade de toda uma nova arte que se define como humanista” (GULLAR, Ferreira. “Opinião 65”5 apud AMARAL, 1984, p. 330).

$\mathrm{Na}$ análise das colunas de crítica, sobre as artes plásticas, publicadas na imprensa, nota-se que na exposição "Opinião 65", o grande destaque foi a participação, polêmica, de Hélio Oiticica, a apresentação de sua obra intitulada "Parangolé" e o happening organizado para a mostra:

[...] Hélio Oiticica realiza la primera presentación pública de sus parangolés em la exposición Opinião 65 em el Museu de Arte Moderna do Rio de Janeiro (MAM). Oiticica protagonizó entonces uno de los episodios mas famosos del arte brasileño [...] Oiticica planeó mostrar sus parangolé, por primera vez, em la inauguración de la exposición colectiva Opinião 65 [...] Oiticica convoco para la apertura de la exposición a su amigos de la favela de Mangueira, invitándolos a entrar em procesión al museu, bailando samba, vistiendo las capas y flameando las banderas. Los directivos del museu, prohibieron su danza [...] Com el artista furioso, el desfile continuó por el parque que rodea al edifício de Eduardo Affonso Reidy, aplaudido por otros artistas, periodistas y audiência (MALBRÁN, 2018, p. 18).

$\mathrm{O}$ fato de proibirem o happening - com os passistas da escola de samba Mangueira, pessoas

4 [...] "Com o advento da ditadura militar, Mário Pedrosa intensifica a sua militância política, que aliás nunca o abandonara, no sentido de se engajar em um processo de luta pela redemocratização do qual participaram diversos intelectuais e artistas. [...] Esse processo, e um posterior decreto de prisão, levariam-no a se exilar no Chile [em 1970], só retornando ao Brasil em 1977" (BARROS, 2008, p.57).

5 Texto original publicado na Revista Civilização Brasileira, (4), set.1965 e em Arte em Revista (2), maio/ago, 1979. 
pobres e negras oriundas das favelas da cidade do Rio de Janeiro - preparado por Oiticica, para a apresentação de sua obra, evidencia o distanciamento do público, mais amplo, das atividades artísticas, sobretudo das artes plásticas. A proibição do acesso ao local da mostra - MAM, RJ -, revelava o caráter, ainda elitista, do evento, rejeitada por Oiticica e demais artistas que reivindicavam a democratização das artes. Vale ressaltar, que a criação dos "Parangolés" era destaque na imprensa, antes mesmo de ser apresentada ao público: "Hélio Oiticica anda entusiasmado com a sua nova criação: um penetrável parangolé que está construindo. Trata-se de uma verdadeira revolução, dentro da sua experiência de pintura no espaço tridimensional. Já em si revolucionária" (PETER. "Panorama". Jornal do Brasil, 18 de setembro de 1964 - Caderno B, p.4).

A criação de Hélio Oiticica, mantinha-se em destaque na imprensa. Caracterizado como inventivo e polêmico, o artista seguia apresentando suas obras em exposição individual, realizada na Galeria G-4, em Copacabana, no Rio de Janeiro, espaço que se caracterizava pelas experiências artísticas de vanguarda.

A exposição intitulada "Manifestação Ambiental no 1", apresentava bólides (caixas) e núcleos (penetráveis), provocou impacto, pelas escolhas realizadas - como a homenagem ao bandido "Cara de Cavalo", amigo de Oiticica, em razão de sua convivência no Morro da Mangueira - e a proposta de participação do público que as obras possibilitavam:

[...] Na noite de segunda-feira, apesar do grande número de mostras programadas, a galeria ficou lotada para ver os objetos resultantes do espírito inventivo de Oiticica. O resultado é uma série de trabalhos em que o público funciona como participante na obra de criação artística, podendo modificá-las para descobrir novos efeitos de côr, volumes, composição etc. Dois grandes labirintos em secções de madeira pendentes de fio plástico separam a mostra em ambientes, obrigando o expectador a transpô-los para passar de uma parte à outra. Um dos trabalhos que chama a atenção é uma homenagem ao famoso Cara de Cavalo. Trata-se de uma caixa de madeira em que o cadáver do bandido é visto nas quatro faces internas em fotografias feitas pela equipe do JB. À entrada, pelo menos na noite da inauguração, uma tocha de fogo sinalizava a porta da galeria. Da G-4 a mostra de Oiticica vai para a Galeria Signals, de Londres (Jornal do Brasil, 23 de junho de 1966, Caderno B, p.3).

“Cara de Cavalo, o tema da bólide, foi assassinado pelo Esquadrão da Morte. Era considerado pela sociedade como um bandido perigoso. Mas para Oiticica ele representava um herói, ou seja, o contrário da visão negativa de marginal” (CAVALCANTI, 2005, p.165).

A inauguração da exposição de Oiticica, na Galeria G-4, foi marcada por acontecimentos provocativos: [...] “a certa altura, o gravador Rubens Gershman [sic] atirou um ovo, das inúmeras cestas espalhadas pelo chão, num fotógrafo. Mas tudo ficou aî” [...] (Jornal do Brasil, 22 de junho de 1966, Caderno B, p.3). Na ocasião, houve também, palestra informal sobre os happenings, o que pode explicar a atitude de Gerchman. Sobre a proposição estética de Oiticica, o crítico Harry Laus (1922-1992), escreveu a respeito:

[...] o que Hélio Oiticica visa acima de tudo é a participação do público que de espectador passe a participador. Quando uma criança está brincando com um desses brinquedos japoneses de papel que se transformam ao movimento das mãos, passa-se em seu íntimo a alegria da criação. Hélio pretende ir mais longe porque suas caixas (bólides) oferecem um sem número de combinações. A própria capacidade sensível do participador enriquece a obra criada [....] Todos os intelectuais são chatos e otários - declara Oiticica. Sua arte é dirigida às pessoas simples que melhor a compreendem. O intelecto é uma inibição. Trazer o sentido místico das coisas, destruindo o lado intelectual é sua intenção. $\mathrm{Na}$ verdade, as pessoas passam a vida aprendendo idéias feitas e depois, se quiserem evoluir, têm que esquecê-las [...] A arte (ou antiarte) de Hélio 
Oiticica pretende uma complementação da necessidade coletiva de uma atividade criadora latente. A obra do artista no que possuiria de fixa só toma sentido e se completa ante a atitude de cada participador. É uma atitude extrovertida em relação à arte. Não o respeito a ela como se se tratasse de um objeto religioso ou de culto mas uma atitude de quem participa, a arte ganhando assim um atributo vital que muitas vezes lhe é negado (Jornal do Brasil, 20 de julho e 1966, Caderno B, p.2).

As manifestações artísticas apresentadas despertavam o interesse sobre a "vanguarda artística" brasileira. E, em agosto de 1966, o crítico de arte e professor Frederico Morais (1936), organizou uma exposição, convidando oito artistas, nomeadamente: Antônio Dias, Ângelo de Aquino, Carlos Vergara, Dileny Campos, Hélio Oiticica, Maria do Carmo Secco, Pedro Escosteguy e Rubens Gerchman, para mostra a ser realizada em Belo Horizonte, Minas Gerais. A atividade ocorreu na Universidade de Minas Gerais, com apoio da Reitoria, fato que mereceu elogios e destaque na imprensa, uma vez que, em razão da oposição do movimento estudantil ao governo autoritário, as atividades com a participação de estudantes sofriam repressão e eram consideradas "subversivas":

[...] Surpreendentemente - para os tempos que correm - foi obtido apoio oficial à iniciativa do crítico. O Magnífico Reitor da Universidade, Prof. Aluísio Pimenta, demonstrando ser possuidor de um espírito aberto às novas conquistas da arte e querendo, como aliás lhe compete, informar seu clã sôbre o nôvo e o atual no campo artístico, como o faz no campo científico, aderiu de corpo e alma à idéia pioneira de Frederico Morais. Exemplo a ser seguido por outras reitorias, de outros estados (LAUS, Harry. "A vanguarda ataca Minas". Jornal do Brasil, 02 de agosto de 1966, Caderno B, p.2).

Na coluna "Artes", Harry Laus, seguia destacando as atividades da exposição, que fora apresentada com o "cartaz-catálogo", elaborado por Rubens Gerchman. Na cor vermelha, o sinal de pare alertava sobre os artistas, com dados biográficos, depoimentos, fotos e análises críticas sobre as obras e a apresentação em texto de Frederico Morais. O evento promoveu, ainda, um debate entre artistas e público, corroborando a atitude de democratização das artes. Mas, se o crítico revelava entusiasmo com a atitude do Reitor em apoiar a exposição, o público - formado prioritariamente por jovens universitários - decepcionou, conforme destacou na coluna:

[...] No prometido debate, Antônio Dias, Escoteguy e o próprio Gerchman projetaram diapositivos para melhor esclarecimento do público. A não ser um professor que levou mais a fundo suas indagações sôbre o sentido de um trabalho de Escosteguy (O Circo Atômico), as perguntas em geral foram superficiais (por que usa o vermelho? por que pinta ima seta?), denotando, a nosso ver, falta de informação ou preocupação artística [...] (LAUS, Harry. "A vanguarda ataca Minas". Jornal do Brasil, 02 de agosto de 1966, Caderno B, p.2).

Mas, mesmo com a falta de informação, da maioria do público, ou a preocupação artística, a discussão em torno da vanguarda artística, mantinha-se em debate no cenário brasileiro e era repercutida com destaque na imprensa, mesmo que atingisse apenas a classe média, leitora dos periódicos analisados.

Em 25 de agosto de 1966, era inaugurada a exposição "Opinião 66", no MAM/RJ, com a participação de 52 artistas $^{6}$, entre brasileiros e estrangeiros. Das obras a serem apresentadas, a

\footnotetext{
6 “Brasil: Dileny Campos, Valdemar Cordeiro, Raul Córdula, Antônio Dias, Pedro Escosteguy, Rubens Gerchman, Gastão Manuel Henrique, Renato Landim, Francisco Liberato, Hélio Oiticica, Glauco Rodrigues, Maria do Carmo Secco, Ivã [sic] Serpa, Antônio Carlos Vergara; Argentina: Oscar Bonny, Délia Cancella, Mendez Casariego, Edgardo Eyheraldo, Pablo Mesejean, Eduardo Scornavache, Antônio Trotta, Jack Vanarki;
} 
expectativa em torno da criação de Hélio Oiticica, novamente, era ressaltada:

[...] No conjunto brasileiro, Hélio Oiticica promete algumas novidades sensacionais. Todos estão lembrados de que no ano passado êle apresentou o Parangolé que foi muito comentado e pouco compreendido. Para Opinião 66 imaginou o Parangolé Lúdico que se trata de um jogo de bilhar. Até o momento em que escrevemos esta notícia, Hélio ainda não havia conseguido a mesa, mas mesmo assim pede que "quem jogar bilhar venha com uma camisa bem luminosa". Além deste trabalho, mostrará nova capa feita com auxílio de Gerchman e intitulada A Bandeira Brasileira, assim, outra homenagem ao passista-mirim da Escola de Samba de Mangueira, o menino Mosquito [...] (LAUS, Harry. "A Opinião de cada um”. Jornal do Brasil, 24 de agosto de 1966, Caderno B, p.2 - grifos originais do texto).

“Oiticica concebia a prática de vanguarda como uma forma de 'anti-arte', uma crítica total dos contextos sociais e institucionais para a produção de um determinado objeto que é reconhecido, valorizado e consumido como arte" (DUNN, 2008, p. 151). Para o artista, não interessava mais a produção de "obras" para serem contempladas, mas caberia ao artista propor uma experiência, que exigiria a participação ativa na criação artística. E, ainda, sobre o processo criativo e contribuição de Oiticica, afirmou-se que:

[...] Um dos mais consequentes artistas dos anos 60 - [...] à sua maneira, [chega a abordar] alguns procedimentos críticos dadaístas com a vocação construtiva oriunda do concretismo, o artista chega igualmente tanto à superação da dicotomia pintura/escultura quanto à problematização radical da relação figura/suporte, tudo imerso num denso caldo crítico permeado à mítica sociocultural dos morros cariocas [...] (FREITAS, 2004, p. 78).

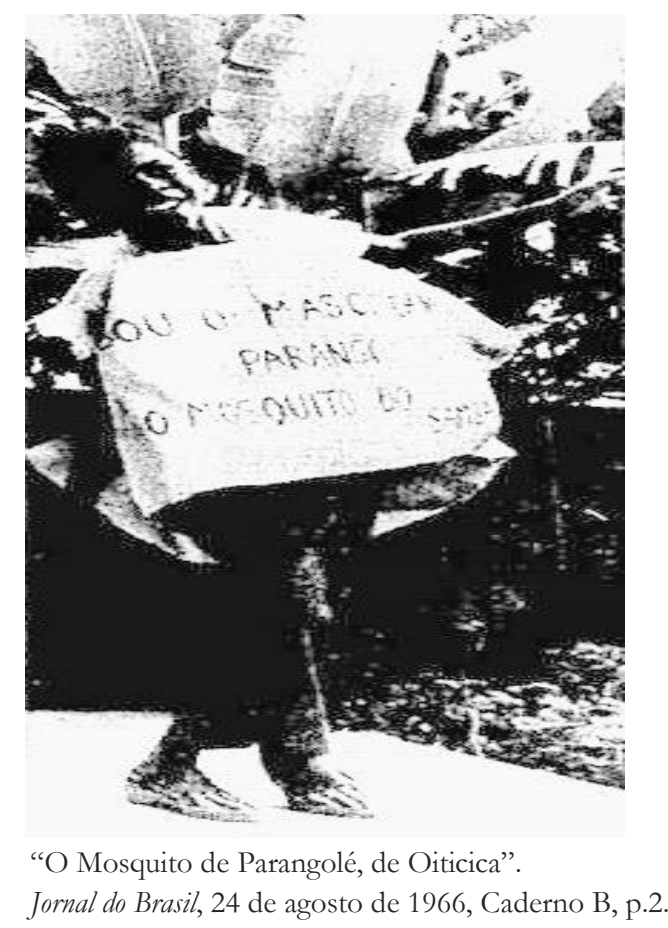

França: artista de diversas nacionalidades, residentes em Paris: Rou Adzak, Edmund Allayen, Atila, Francis Biras, Corneille, Claude Dronda, Peter Foldes, Guy Frangin, Janis Galtis, Lea Lublin, Michel Macreau, Emanuel Poweler, Bernard Raniellae, António Berni, Gérard Tisserand; Suécia: Bengt Bockman, Johnny Nilsson; Uruguai: Ernesto Cristiani, Jorge Paez, Ruisdael Suares; Espanha: Juan Genoves, José Jardiel, Alejandro Marcos, Robert Munford; Itália: Ana Maria Maiolino, Cesare Peuerelli, Giovanni Rubino; Japão: Ikeda Masuo; Estados Unidos: Hugh Weiss; Holanda: Jacob Zekveld" (LAUS, Harry. A Opinião de cada um. Jornal do Brasil, 24 de agosto de 1966, Caderno B, p.2). 
As inovações no campo das artes plásticas, o caráter experimental das criações, tornavamse questões centrais no debate de críticos de arte, artistas e intelectuais. A situação do artista e a "massificação" da produção artística ocupavam as discussões. Sobre o tema e, em análise do cenário artístico, Mário Pedrosa salientava que a liberdade caracterizava o ambiente artístico. Assim afirmou:

[...] Estamos agora interessados em cercar o problema tão complexo e contraditório de condição do artista na sociedade moderna. É esta uma preliminar indispensável para se compreender a posição não só da arte atualíssima atual como de seus artistas, sobretudo do pop (com todas as as variações e designações que cabem dentro daquela sílaba tão vasta e tão abstrata). Creio não ser exagero afirmar que o traço decisivo que caracteriza o comportamento artístico de agora é a liberdade, ou o sentimento de uma liberdade nova. Já faz bastante tempo que, tentando analisar o fenômeno, define a arte de nossos dias como o exercício experimental da liberdade [...] (PEDROSA, Mário. “O 'bicho-da-sêda' na produção em massa”. Jornal Correio da Manhã, 14 de agosto de 1966, p.3).

Mário Pedrosa constatava o que denominou de "regime de produção em massa", a automação mecânica e o caráter mercantil na criação artística. E alertava que, só após a superação do mercado, num regime pós-capitalista, o artista recuperaria seu papel independente e não mais alienado, experimentaria de fato, o exercício da liberdade. Na coluna, seguia argumentando e apresentando questões relevantes que ampliavam o debate:

[...] os artistas de hoje não só tomaram consciência como os seus maiores, de que são bichosda-sêda, como tomaram consciência de um impulso nôvo que os impele ao uso da liberdade. De onde vem êsse impulso? Mas onde estão as condições sociais e culturais que permitam a êsses bichos continuarem a produzir incessantemente a sua sêda e usar de seu dom natural em tôda liberdade? Como conservá-la em sua autenticidade originária e como distribuí-la, sem alterá-la na sua existência intrínseca, ou como doá-la, tocá-la numa sociedade como sêdas sintéticas em abundância e entregue às mobilizações em massa e os divertimentos em massa? (PEDROSA, Mário. “O 'bicho-da-sêda' na produção em massa”. Jornal Correio da Manhã, 14 de agosto de 1966, p.3).

Na década de 1960, o crítico de arte, Frederico Morais ${ }^{7}$, transferiu-se de Minas Gerais para o Rio de Janeiro, onde figurou como expoente no cenário artístico. Em 1966, foi convidado a assumir o Departamento de cursos do MAM/RJ, que promovia vários cursos livres, atividades lúdicas e oficinas. No mesmo ano, tornou-se redator da coluna "Artes Plásticas" no Jornal Diário de Notícias. Sobre a mudança para o Rio de Janeiro e a estreia da coluna, escreveu:

Uai, você também! É ... estou vindo, O poeta Drummond ("tinha que ser", como quer o general Guedes, se é de Minas, é êle quem fala), poderia dizer que como as coisas andam por lá, Minas está proibida até para mineiro. E nóis vamos saindo, ou indo, porque mineiro é gerundial no verbo e na ação (nem saímos, nem chegamos) [...] E esta coluna, que sairá às têrças, quintas, sábados e domingos. Quero fazê-la dinâmica, na medida do possível bem informativa. E com firme propósito de só comentar o que é bom, e de vanguarda. Vanguarda mesmo: arte pós-moderna, anti-arte. E o Rio é, inegavelmente, a sede da vanguarda artística brasileira

\footnotetext{
7 "Seu nome está diretamente relacionado a exposições, salões de arte e eventos extramuros inovadores dos anos 1960/70, e a importância de sua atuação nesses tempos difíceis não pode ser menosprezada. Em vários textos de época, Morais discutiu a função transgressora de um artista de vanguarda que atuava em uma sociedade dividida; pressionada, por um lado, pela força repressiva da ditadura e, por outro, pelo sonho da luta armada e pelo vigor da contracultura" [...] (COUTO, 2019, p. 113).
} 
(MORAIS, Frederico. "Rio e Vanguarda Brasileira", Jornal Diário de Notícias, $1^{\circ}$ de setembro, 1966 - 2º seção, p.3).

Em tom entusiástico, no texto da coluna de estreia, destacava, ainda, a importância da cidade do Rio de Janeiro no cenário artístico - "a sede da vanguarda artística brasileira” -, comparada às cidades de São Paulo e Minas Gerais, na sua opinião, os redutos mais conservadores, e ressaltava a exposição "Opinião 66":

[...] O Rio é, antes de tudo, o uso ilimitado da liberdade criadora. Ausência de qualquer compromisso com as tradições, ou com o que vem de fora. Cidade aberta, sonora, barulhenta, cidade sem raízes, ou, pelo menos, estas não são tão marcantes como em Minas ou em São Paulo. Cidade-côrte, poucos são os artistas aqui nascidos. O Rio é o lugar onde todos acontecem ou tudo acontece. A própria cidade é um acontecimento, desinibida que é. Um "happening" contínuo, o Rio é a festa, o vernissage. Aqui, melhor do que em qualquer lugar, a improvisação perde suas conotações pejorativas e todas as ousadias são incentivadas, o que é bom para a arte [...] Esta disponibilidade para receber e dar, sem arrogância e prepotência, é que tem permitido a renovação constante da arte brasileira atual, no Rio, e o aparecimento de uma espécie de carioquismo (que é um estado de espírito, um comportamento, mais do que um estilo) em nossa arte. Como dá provas, no momento, e mais uma vez, "Opinião 66", exposição ora em curso no Museu de Arte Moderna do Rio, que comentaremos sábado (MORAIS, Frederico. "Rio e Vanguarda Brasileira", Jornal Diário de Notícias, $1^{\circ}$ de setembro, 1966 - 2 seção, p.3).

A exposição "Opinião 66”, seguia em evidência na imprensa e na coluna - "Artes Plásticas" -, Frederico Morais, argumentava sobre a relevância do evento, comparando a realidade brasileira ao cenário estrangeiro, em especial, a França. Em longo texto, discorria sobre as tendências artísticas vigentes na década de 1960, apresentava análise das obras apresentadas na exposição, criticando as proposições estéticas elaboradas por "oportunismo" ou mero "modismo" e, "elegia" os artistas que representavam a vanguarda brasileira nas artes plásticas:

Antes de mais nada, e preciso dizer que em "Opinião 66", a contribuição brasileira é indiscutivelmente mais alta e significativa [...] Mas a verdadeira opinião brasileira - [...] está nos "Objetos Semoventes" e outras manifestações anti-arte de Lígia Clark; nas "apropriações" e "capas" de Hélio Oiticica, no objeto contundente ("Canalha"), de Valdemar Cordeiro; nos relêvos realistas de Gerchman e suas "Caixas de morar", em Antônio Dias, lamentavelmente mal representado; tudo sob a égide do pós-moderno, da anti-arte e, vejam lá, da antidada. Pois, não venham com simplismos do tipo, isto já foi feito, Duchamp fêz melhor, o Dada é coisa superada. Como diz Pierre Restany "tout est plus ou moins dada aujourd'hui", porém, com um novo espírito. "Tratava-se antes - observou recentemente Rauschemberg - de excluir, era a censura contra o passado, visava seu desaparecimento. Hoje, para nós, trata-se de incluir o movimento, de introduzir o passado no presente, a totalidade no momento. Há grande diferença entre exclusão e inclusão", completou (MORAIS, Frederico. "A Opinião Brasileira de 66”, Jornal Diário de Notícias, 08 de setembro, 1966 - 2 seção, p.3).

Das proposições apresentadas na exposição, a obra do artista Hélio Oiticica continuava a sobressair na imprensa e apresentada pelos críticos de arte, como Frederico Morais, como representação da vanguarda artística brasileira. Sobre as inovações observadas na criação de Oiticica, argumentou:

[...] Ao invés de simplesmente descrever um jogo de bilhar numa favela qualquer, como o fêz Heitor dos Prazeres, Oiticica, que não é ingênuo, trouxe, concretamente, o objeto para a sala 
de exposições. Para elaborar a obra de arte? "Está na capacidade do artista declarar se isso é ou não uma obra, tanto faz que seja coisa ou uma pessoa viva", afirma Oiticica. Mondrian dizia que a arte é um produto de substituição num mundo que carece de beleza. No futuro, dizia ao tempo do neo-plasticismo, quando o homem tiver recuperado o equilíbrio, com o desaparecimento do "trágico", a arte estará perfeitamente integrada na vida. E ela desaparecerá, pois tudo será arte. O campo de aplicação das idéias neo-plásticas não era exclusivamente o quadro de cavalete, mas, sobretudo, o planejamento físico (da arquitetura ao urbanismo) do mundo, que precisa reambientado. Oiticica dando curso às idéias de Mondrian, como se viu recentemente em sua "Manifestação Ambiental no 1, na G-4, quer reeducar visualmente o homem, reintegrálo na beleza e simplicidade do quotidiano, tornando-o mais autêntico é útil (MORAIS, Frederico. Jornal Diário de Notícias, 15 de setembro, 1966 - 2 seção, p.3).

O caráter experimental e as inovações estéticas na criação das obras, contudo, dificultavam a recepção, em razão da pouca informação e distanciamento do público do cenário artístico, em especial, nas artes plásticas. A temática, também, era alvo de ampla discussão entre os críticos e artistas. O estranhamento do público, a dificuldade de compreender as proposições estéticas eram evidenciadas, conforme destaque:

[....] Lígia Clark expôs, além de grande número de caixas de fósforos coladas e "sem a menor intenção", muitos sacos de matéria plástica cheios de água, alguns dos quais com pedras do mar por cima, quase dividindo-os em dois.

- A senhora pode me mostrar onde está a arte nestas suas obras? - perguntou-lhe uma pessoa. - Não se explica - disse Lígia Clark, que acrescentou:

- Comprima levemente um dos sacos e veja se não sente a sensação de um reencontro com o seu próprio corpo.

Salientou que "propõe a comunicação do ato de imanência e do precário como nôvo conceito de existência, contra tôda cristalização do fixo e a duração da transcendência" [...] (Jornal do Brasil, 26 de agosto de 1966, $1^{\circ}$ Caderno, p.5).

Contudo, se algumas das obras desafiavam o público a "decifrá-las", outras propostas eram compreendidas sem dificuldades. Em meio ao contexto autoritário, vivido no Brasil, a denúncia e o protesto figuravam em várias obras:

[...] Na última sala da exposição a figura de um homem gordo, comendo fartamente, foi de sentido facilmente compreensível para todos, pois embaixo estava escrito " $2 / 3$ da Humanidade morre de fome", ao lado de um homem de fisionomia cansada, debruçado num relógio de ponto e rodeado por números que iam do 172 ao 184.

Ainda de fácil compreensão é a figura de um general, com o peito coberto de medalhas, mas com a cabeça substituída por uma caveira e um quadro denominada "norte-americanos preparam contra ameaça comunista no sudeste da Ásia", mostrando um homem, em cima de quem surgiram várias crianças magérrimas, com a nítida intenção de penetrar-lhe o corpo (Jornal do Brasil, 26 de agosto de 1966, $1^{\circ}$ Caderno, p.5).

No período analisado neste estudo, Mário Pedrosa utilizou sua coluna no jornal Correio da Manhã, para apresentar sua análise do cenário das artes plásticas no Brasil e no mundo, além de manifestar, de forma veemente, sua oposição ao governo autoritário. O texto do crítico evidencia que, apesar das medidas autoritárias em vigor no país, desde 1964, a censura aos meios de comunicação, ainda, não era plena. Em apoio ao movimento estudantil ${ }^{8}$, Mário exaltava as ações da

\footnotetext{
8 No período de 1964 a 1968, o principal grupo de oposição ao governo autoritário foi representado pelo movimento estudantil, com a participação de secundaristas e universitários. Manifestavam-se através da panfletagem, passeatas e greves. Reivindicavam reformas educacionais, sobretudo a ampliação de vagas
} 
oposição e avaliava - de forma otimista - que o estado autoritário não perduraria por muito tempo, graças a pressão dos setores sociais que se mobilizavam contra o governo militar:

[...] Mais eis que os estudantes brasileiros também ousem, nas justas lutas por suas próprias reivindicações, ferir as suscetibilidades marechalícias martelando naquela miséria, que é afinal de contas o tema capital, o desafio decisivo que a História nos faz a nós todos, brasileiros de tôdas as classes e de tôdas as idades, e sobretudo a essa heroica mocidade que bordeja os vinte anos e se apresenta cada vez mais como a portadora de uma consciência nova (PEDROSA, Mário. "Brava, brava mocidade". Jornal Correio da Manbã, 18 de setembro de 1966, 4 Caderno, p.3).

No cenário das artes, o ano de 1966, no Brasil, foi encerrado com a realização da I Bienal de Artes Plásticas da Bahia, ocorrida entre os dias 26 de dezembro à 28 de fevereiro de 1967, no Convento do Carmo, em Salvador, que [...] "conseguiu reunir 162 obras, de 79 artistas de São Paulo, 234 trabalhos de 98 autôres da Guanabara, 221 obras de 105 artistas baianos, mais 138 criações de 60 artistas dos demais Estados, num total de 755 obras de arte de 342 artistas de todos o País" [...] (Jornal do Brasil, 27 de dezembro de 1966, Caderno B, p.4). Harry Laus, realçava em sua coluna "Arte", a influência das tendências de vanguarda nas obras, como a nova figuração e a pop art. [...] Lênio Braga, melhor representado por seus desenhos, apresenta um curioso Monalisa e Moneyleague, com a presença da infalível Coca-Cola" (Jornal do Brasil, 27 de dezembro de 1966, Caderno B, p.4).

Dos artistas brasileiros participantes na Bienal, em Salvador, a maior premiação coube à Lygia Clark - que apresentou uma retrospectiva de suas obras -, que recebeu o valor de 5 milhões de cruzeiros. O júri foi composto por Mário Pedrosa, Mário Schemberg, Clarival Valadares, Wilson Martins e Riolan Coutinho. O Prêmio Nacional de Pesquisa, no valor de 3 milhões de cruzeiros, foi recebido por Rubens Gerchman, que com o uso de diversos materias, como: acrílico, chapas coloridas usadas em cartazes de rua e poliéster, apresenteou a série de "Caixas de Morar", que foi considerada de vanguarda:

[...] é uma construção de madeira com 2,50 m de altura, pintada com tinta plástica, havendo no alto um letreiro em neon, num verde de botequim, anunciando novas caixas de morar. Além dêste, existem ainda um elevador social, cheio de pessoas, uma marmita de operário, com quatro superfícies, numa das quais está um horário de trabalho, uma caixa de origem, "a primeira caixa de morar do indivíduo", e a caixa de um homem só, onde a curiosidade é a existência de um espêho biseauté "daqueles usados em molduras de porta-retratos de mau gôsto", onde está desenhado um coração vermelho, com uma inscrição: "Eu te amo" (Jornal do Brasil, 30 de dezembro de $1966,1^{\circ}$ Caderno, p. 10 - grifo original do texto.).

"Rubens Gerchman também investigou a identidade do homem massificado na cidade grande, caótica e fragmentada [...] pintava a realidade que percebia, ou seja, a multidão, o indivíduo

no ensino superior e a reforma dos currículos escolares, além de denunciarem as medidas de cerceamento e coerção dos governos militares. Tais manifestações foram duramente reprimidas, sendo que o episódio do assassinato do estudante secundarista Edson Luís de Lima Souto, em 28 de março de 1968, que durante protestos realizados no Restaurante Calabouço, no Rio de Janeiro, resultou na ampliação dos protestos estudantis, que contaram com a solidariedade e adesão de diversos setores da sociedade brasileira, notabilizada na "Marcha do Cem Mil", realizada em 26 de junho de 1968, no Rio de Janeiro. O movimento estudantil, no Brasil, entrou em declínio após a prisão de cerca de mil estudantes e das principais lideranças estudantis na ocasião da realização do XXX Congresso da União Nacional dos Estudantes - UNE, em outubro de 1968. 
solitário e anônimo na cidade grande, e os sentimentos desses indvíduos" [...] (ABREU, 2018, p. 62-64). E, sobre seu processo critativo, a comunicação com o público e a crítica social apresentada em sua obra, o artista comentou:

[...] O espectador de hoje é desatento, cansado, talvez pelas atribulações da vida cotidiana começou êle. Recebe um número maior de informações diárias do que, por exemplo, o espectador dos anos 40. É muito mais solicitado. Portanto, o artista, penso eu, deve usar tôdas as técnicas de comunicação possíveis. Uma delas é pegar o espectador pelo pescoco, fazê-lo parar e pensar. Tarefa dura. Assim, considero válidas as técnicas do cartaz de cinema, da história em quadrinho etc. A crítica social pode ou não estar presente em meus trabalhos, mas apresento sempre o homem urbano em seus múltiplos aspectos. Neste sentido, faço crítica social representando o homem massificado, desinvidualizado na sua solidão, nas suas limitações, dentro de sua caixa [...] (LAUS, Harry. "O problema das caixas". Jornal do Brasil, 27 de janeiro de 1967, Caderno B, p.2).

A premiação resultou em protesto do artista Franz Krajcberg' ${ }^{9}$, que recebeu 2 milhões de cruzeiros em prêmio especial, que recusou e retirou-se do recinto da Bienal com seus trabalhos, após a premiação concedida à Lygia Clark. O artista declarou tratar-se de perseguição dos jurados, nomeadamente de Mário Pedrosa. E, sobre a atitude, o artista justificou-se, em tom acusatório:

[...] Fiquei indignado - afirmou - com êsse júri provinciano, mas acho que esta foi a última experiência que fiz e em que mais uma vez recebi insulto de Mário Pedrosa. Quero crer que pela última vez. $\mathrm{O}$ meu protesto é indignação por ter caído numa armadilha. Vim à Bahia disposto a não participar, achando que devia entrar somente como hors concurs, uma vez que não haveria julgamento para as salas especiais. Mário Pedrosa convence-o depois de instituir prêmio para essas salas, mas já falava no Grande Prêmio para [...] (Jornal do Brasil, 30 de dezembro de $1966,1^{\circ}$ Caderno, p. 10).

A atitude do artista resultou em mudanças na premiação, pois: "A última hora o júri, apesar da oposição de Mário Pedrosa, decidiu redistribuir os 2 milhões recusados por Kracjberg, favorecendo a mais sete artistas com prêmios de 300 a 200 mil cruzeiros" (HAUS, Larry. Artes. Jornal do Brasil, 05 de janeiro de 1968, Caderno B, p. 2). A decisão do júri continuava a repercutir e sobre a premiação concedida à Lygia Clark, destacou-se:

[...] Lígia foi lá participar da Bienal. Sua bagagem continha mais de 40 trabalhos: trepantes de metal e de borracha, caixas de metal, relêvo, contra-relevos, superfícies modulada, ôvo, casulo e seus já famosos bichos, com ou sem dobradiça.

- O páreo foi duro. Todos os artistas que tiveram salas especiais eram de alto gabarito e consagrados no meio artístico.

Acontece que Lígia venceu. E a Bahia teve o privilégio de ver obras inéditas, além de alguns projetinhos de arquitetura: A Casa do Bicho, A Hora de Lazer para o Homem Contemporâneo, Arquitetura Fantástica (montagem em fotografia), Estudo para a Próxima Feira da Guanabara (de Max Bagdócimo, em co-autoria com Hélio Oiticica), A Casa do Poeta [...] (Jornal do Brasil, 08 de janeiro de 1967 - Revista de Domingo, p.3).

9 Artista polonês, de origem judaica [... "no período de 1958 a 1963, viveu entre o Rio, Paris e Ibiza, na Espanha, onde instalou um ateliê numa gruta e começou a fazer suas primeiras 'impressões de rochas', conhecidas também como seus 'quadros de terra e pedra'. [...] Em 1964, volta para o Brasil, Minas Gerais, em Cata Branca, região próxima ao pico de Itabirito. Lá, Krajcberg morou cinco anos de uma Kombi, solitário e recluso. [...] Foi nesse momento de sua trajetória artística que começaram a ser criadas as suas primeiras esculturas com troncos de árvores, já mortas pela ação do homem”[...] (FERNANDINO, 2014, p. 264-265). 
Além da polêmica em torno da premiação, as proposições estéticas apresentadas na Bienal da Bahia, repercutiam na imprensa. Das criações, mais uma vez, a obra de Hélio Oiticica era realçada, pelo uso dos materiais e, sobretudo, por estabelecer uma nova relação entre o público e a obra, ou seja, por provocar e possibilitar a participação:

[...] Oiticica apresentação três núcleos da Manifestação Ambiental no 2, compostos de placas de madeira pintadas a óleo e plastificadas com vinil, suspensas do teto por fios. O chão foi recoberto por pedras britadas que obrigam o visitante a percorrer o labirinto das placas, já que em sua projecção não há pedras. Com êstes trablhos, onde prevalece o amarelo em diversas tonalidades, Oiticica, mereceu o prêmio especial de dois milhões, "pelas suas pesquisas de ambientes" (HAUSS, Larry. "Especiais na Bienal Baiana". Jornal do Brasil, 08 de janeiro de 1967, Caderno B, p. 2).

Mário Pedrosa - que participou do júri da I Bienal da Bahia - apresentou, em sua coluna, suas considerações sobre o evento. $\mathrm{Na}$ análise, ressaltou a importância do evento realizado em Salvador, que favorecia o deslocamento dos grandes centros artísticos - São Paulo e Rio de Janeiro -, evidenciou a pluralidade das proposições estéticas vigentes no Brasil, suas influências e comparando a criação de artistas, afirmou:

[...] A Bienal da Bahia, ou como a denominam seus idealizadores, e com justeza, primeira Bienal Nacional de Artes Plásticas, me reavivou a reflexão sôbre aquêle conceito [contemporaneidade] [...] Não vai na reflexão a menor restrição ao conteúdo e ao valor instrínseco daquele certame. Constatamos ali, ao contrário, um fato de extremo interêsse, interêsse artístico, estético, antropológico e mesmo sociológico. Nesse sentido as salas especiais no Convento do Carmo ofereceram um quadro quase perfeito da relação do conceito, quanto ao espaço histórico, ou os diferentes níveis de contemporaneidade ali representados [...] Houve, mesmo confronto de atitudes estéticas [...] Veja-se, digamos, o contraste entre a sala de um [Francisco] Brennand e a sala de [Lygia] Clark. Ambos são brasileiros de muitas gerações. [...] O Brasil é ao mesmo tempo um anacronismo e uma promessa. Para certos de seus artistas, a tarefa contemporânea consiste em expressar êsse anacronismo, como se se tratasse de uma operação de catarse, para a seguir subsumí-lo no universal. Outros, porém, partindo do universal contemporâneo implícito na promessa, aceitam, já agora, no seu trabalho criativo, o condicionamento de amanhã e não o condicionamento de ontem. A distância de pontos de partida entre um Francisco Brennand e mesmo um Rubem Valentim e Lígia Clark ou Hélio Oiticica é grande. Mas que há entre êles em comum além do fato cultural e moral de serem brasileiros? A autenticidade de uma vivência pessoal por que responde a própria obra? Antes a responsabilidade por uma idéia ou por uma atitude que, se mantém, se desenvolve e os caracteriza através do trabalho criativo, não veio de fora, por acaso ou por moda, mas brotou nêles do complexo sócio-econômico-cultural-moral-artístico, onde se situam, onde vivem, trabalham, Recife ou Salvador, São Paulo, Rio de Janeiro, Brasil ... e inevitávelmente o planêta (PEDROSA, Mário. "Contemporaneidade dos artistas brasileiros na Bahia”. Jornal Correio da Manbã, 29 de janeiro de 1967, $4^{\circ}$ Caderno, p.5 - grifos originais do texto).

Entre os dias 6 a 30 abril de 1967, o MAM-RJ promoveu dois eventos simultâneos de artes plásticas, contribuindo para ampliar o debate em torno das vanguardas artísticas. O "V Resumo de Arte”, patrocinado pelo Jornal do Brasil, com homenagem a Ismael Néri, e a exposição intitulada "Nova Objetividade Brasileira"10, organizada por Hélio Oiticica, Hans Haudenschild, Maurício

10 [...] "Participaram da exposição os artistas, constantes em seu catálogo, Aluísio Carvão, Alberto Aliberto, Anna Maria Maiolino, Antônio Dias, Avatar Moraes, Carlos Vergara, Carlos Zílio, Eduardo Lins Clark, Ferreira 
Nogueira Lima, Pedro Escosteguy, Rubens Gerchman e Frederico Morais, sendo que este último, desligou-se do evento, antes mesmo da inauguração da mostra, e foi substituído por Mário Barata. Sobre a decisão do crítico, afirmou-se que:

ROMPIMENTO - O crítico Frederico Morais desligou-se da exposição Nova Objetividade Brasileira que será inaugurada hoje no MAM juntamente com o V Resumo de Arte JB. Alega o crítico que a exposição, com a inclusão de certos artistas de atividades paralelas, na sua retrospectiva, bem como na quebra de proporcionalidade entre o número de expositores e obras de arte entre si e especialmente entre cariocas e paulistas, fugindo dos critérios aceitos inicialmente, perdeu o rigor e a objetividade necessários, sendo grande a defasagem entre a idéia central, motivadora, e a mostra a ser inaugurada. Ficou uma objetividade em família, no dizer do crítico. Devido ao rompimento com a exposição (por princípio apenas), Frederico Morais deixou de elaborar o texto de apresentação da mostra, bem como o que seria o núcleo de um número especial da revista Tempo Brasileiro sobre a mostra, assim como não assume nenhuma responsabilidade quanto à exposição, inclusive sua coluna do Diário de Notícias está explicando com mais detalhes o seu rompimento. (Jornal do Brasil, quinta-feira, 6 de abril de 1967, Caderno B, p. 4).

A exposição "Nova Objetividade Brasileira" era anunciada com grande expectativa. A participação de Hélio Oiticica, com obras que exploravam o aspecto sensorial, sobressaia-se na imprensa:

[...] A exposição Nova Objetividade Brasileira, montada no Museu de Arte Moderna, recebe em sua fase final (encerra-se domingo juntamente com o Resumo de Arte JB) a importante contribuição de uma sala com trabalhos de Hélio Oiticica. Dentro do museu foi montada sua Tropicália que comporta um jardim e até duas araras. Os penetrantes se encarregam de fazer o espectador participar da obra pelo tato, olfato, visão e audição. No domingo, às 5 horas da tarde, o artista estará presente para explicar o sentido de seu trabalho e convida a todos que lá compareçam, inclusive para usar seus trajes intitulados Parangolé [...] (Jornal do Brasil, 05 de maio de 1967, Caderno B, p.4).

Constituída por cerca de 47 expositores, reunindo obras executadas entre 1952 e 1967, a exposição objetivava apresentar o percurso das proposições estéticas no Brasil, que representavam a vanguarda nas artes plásticas. Ao reunir obras produzidas num período de quase duas décadas, evidenciava-se, também, as influências que marcavam as obras, as mudanças no uso de materiais e as tendências artísticas no final da década de 1960. A "nova objetividade brasileira" pretendida, foi explicada da seguinte forma, por Hélio Oiticica, em texto ${ }^{11}$ publicado no catálogo da mostra:

\footnotetext{
"Nova Objetividade" seria a formulação de um estado típico da arte brasileira de vanguarda atual, cujas principais características são: 1) vontade construtiva geral; 2) tendência para o objeto ao ser negado e superado o quadro de cavalete; 3) participação do espectador (corporal,
}

Gullar, Flávio Império, Gastão Manuel Henrique, Geraldo de Barros, Glauco Rodrigues, Hans Haudenschild, Hélio Oiticica, Ivan Serpa, Juvenal Hahne Junior, Luiz Gonzaga Rocha Leite, Lygia Clark, Lygia Pape, Marcello Nitsche, Maria do Carmo Secco, Maria Helena Chartuni, Maurício Nogueira Lima, Mona Gorovitz, Nelson Leirner, Pedro Escosteguy, Raymundo Colares, Roberta Oiticica, Roberto Amaro Lanari, Roberto MagaIhães, Rubens Gerchman, Sami Mattar, Samuel Szpigel, Sergio Ferro, Solange Escosteguy, Theresa Simões, Vera Ilce, Waldemar Cordeiro e Walter Smetak. Como convidados, participaram os artistas Amilcar de Castro e Franz Weissmann, os fotógrafos David Usurpator, Fernando Goldgaber, Pedro Moraes e os cineastas Antonio Carlos da Fontoura e Arnaldo Jabor" (REIS, 2017, p. 101).

11 O texto original: "Esquema geral da Nova Objetividade", pode ser consultado na obra: OITICICA, Hélio. Aspiro ao grande labirinto. Rio de Janeiro: Rocco, 1986. 
tácito, visual, semântica); 4) abordagem e tomada de posição em relação a problemas políticos, sociais e éticos; 5) tendência a uma arte coletiva e consequente abolição dos "ismos" característicos da primeira metade do século na arte de hoje (tendência esta que pode ser englobada no conceito de "arte pós-moderna", de Mário Pedrosa); 6) ressurgimento e novas formulações do conceito de anti-arte. - A "Nova Objetividade" sendo, pois, um estado da arte brasileira atual, o é, também no plano internacional, diferenciando-se, pois, das duas grandes manifestações de hoje: Pop e Op, e também das ligadas a essas correntes: "Nouveau Realisme" e "HardEdge" (ou "Primary Structures"). A "Nova Objetividade", se é um estado atual da nossa arte, não é, pois, um movimento dogmático, esteticista (como o Cubismo e os demais "ismos" construídos como uma "unidade de pensamento"), mas uma "chegada", constituída de múltiplas tendências, onde a "falta de unidade de pensamento" é uma característica importante, sendo, entretanto, a unidade dêsse conceito de "nova objetividade", uma constatação geral dessas tendências múltiplas agrupadas em tendências gerais aí verificadas. Um símile, se quisermos, podemos encontrar no Dadá, guardando as distâncias e diferenças (MORAIS, Frederico. Jornal Diário de Notícias, 29 de dezembro de 1966, $2^{a}$ seção, p.3).

A efervescência do campo artístico, movimentado por diversas exposições, debates, cursos de História da Arte, atividades lúdicas, entre outras e, o contexto autoritário instaurado no país, com medidas de cerceamento das liberdades, gradativamente, sendo ampliadas, repercutia entre os artistas, críticos e intelectuais. O tema da vanguarda dividia opiniões, revelando a pluralidade de concepções e compromissos. Em maio de 1967, Ferreira Gullar publicou suas considerações a respeito do tema, posicionando-se em defesa da produção artística vinculada à realidade social:

[...] De fato, estamos todos de tal modo imersos na vida de todo dia, nosso trabalho está de tal maneira ligado a ela que, se amanhã se proibir qualquer manifestação artística que verse sobre os problemas nacionais, teremos sido golpeados culturalmente, teremos sido emudecidos, enquanto que outros, mais interessados nas questões formais, poderão continuar a publicar seus artigos e seus poemas. E talvez mesmo a ditadura se apóie nesses artigos para justificar o golpe contra os que falam, em suas obras, dessa coisa desinteressante que é a realidade social. Não pretendemos, com isso, nos pôr a salvo das críticas que se desejem fazer ao nosso trabalho, mas apenas acentuar como êsse trabalho está ligado ao presente da vida brasileira. E também porque essa ligação ao presente nos parece uma das condições essenciais da vanguarda cultural e artística, sendo-nos difícil, por isso mesmo, conceber uma vanguarda intena a modificações tão graves como as que têm ocorrido na vida social brasileira. Trata-se então, de uma atividade cultural supra-histórica? Em nosso entender, o povo brasileiro vive um período decisivo de sua emancipação econômica, política e cultural. Como pode representar a vanguarda da arte brasileira uma atividade que não participa dessa luta? [...] (GULLAR, Ferreira. Jornal Correio da Manhã, 07 de maio de 1967, $4^{\circ}$ Caderno, p. 3).

O tema prevalecia no debate e as tendências demonstradas pela arte no Brasil e no mundo, mobilizavam opiniões divulgadas pela imprensa, a partir dos textos de críticos de arte e entrevistas de artistas que se posicionavam. E, em setembro de 1967, o crítico francês Pierre Restany ${ }^{12}$ e o artista, também francês, César Baldaccini ${ }^{13}$ visitaram o Brasil e por meio de interevenções,

12 [...] "A década de 1960 coincidiu também com a participação de Restany no debate sobre a crise dos museus e das instituições culturais francesas na arte contemporânea, e o início de um interesse pela produção artística das 'zonas periféricas' do mundo. Paralelamente ao que se registrava a nível internacional, Restany intensificou o próprio interesse pelas culturas latino-americanas, de acordo com uma tendência que vinha se registrando sobretudo na França: um interesse privilegiado pela América Latina considerada uma zona franca, ainda não tocada pelo processo de modernização entendido como americanização da vida cotidiana. Devido às frequentações à América Latina, que, a partir de 1961, seguiram praticamente ininterruptas até a década de 1980" (PALUMBO, 2018, p. 61-62).

13 [...] "Sua presença no evento [Bienal de São Paulo] acontecera pela primeira vez em 1959, quando o artista apresentara um conjunto de assemblages de ferro e começava a se projetar internacionalmente 
declarações e entrevistas que circularam na imprensa, acrescentaram suas opiniões sobre o cenário das artes plásticas na década de 1960:

[...] O crítico francês Pierre Restany fêz sérias restrições às tendências demonstradas pela arte, nos Estados Unidos, afirmando que os norte-americanos têm uma preocupação tecnológica acima da estética, ao depor, ontem, no Museu da Imagem e do Som [...]

Pierre Restany - que visita o Brasil pela quarta vez - disse ser estimulante o panorama da arte contemporânea no mundo inteiro. Em seguida, fêz uma retrospectiva do que foi a arte francesa dos últimos 20 anos. Disse que vem estudando - com grande atenção - o erotismo na arte, "sempre uma constante, sobretudo em nossos dias". Quanto ao LSD - com que vem de fazer, recentemente uma experiência sob contrôle médico, Restany disse ser "uma liberação contra o pêso do formalismo intelectual" (Jornal Correio da Manhã, 30 de setembro de 1967, p. 7).

Durante sua visita ao Brasil, César Baldaccini realizou uma experiência estética pública, no MAM-RJ, em 6 de outubro de 1967, apresentando suas preocupações formais, a obra foi elaborada, diante do público, para o acervo do museu. O evento atraiu o interesse de vasto público, conforme destaque:

[....] Já se disse que o carioca é o maior "consumidor" de arte do país. E a freqüência de ontem confirmou: entre dezenas de críticos, artistas, colecionadores e desconhecedores de arte, o grande público - funcionários, estudantes, donas de casa, operários, militares, enfim, a massa. O problema de comunição de massas ou a massificação, como a quer Umberto Ecco, estava ali, palpitante, no tempo que durou o trabalho. César quebrou alguns tabus românticos acêrca do "milagre" da criação como ato hermético, inacessível à sensibilidade comum. Dois espetáculos fascinantes a um só tempo: o artista numa espécie de strep-tease espiritual afirmando novas técnicas e novos materiais, e o povo nas mil fac etas de sua fisionomia, fascinado por êsse apêlo latente em todos, no sentido do jôgo de formas e côres. Coisa viva, latejante, fecunda. Como o ato de amar, de fecundar ou parir. Comunicabilidade em grande, áspera e sincera dimensão. Como não se vê nem em atelier ou escolas de arte, com o cinismo da informação ou da aplicação profissional [....] (Jornal Correio da Manbã, 07 de outubro de 1967, $1^{a}$ página).

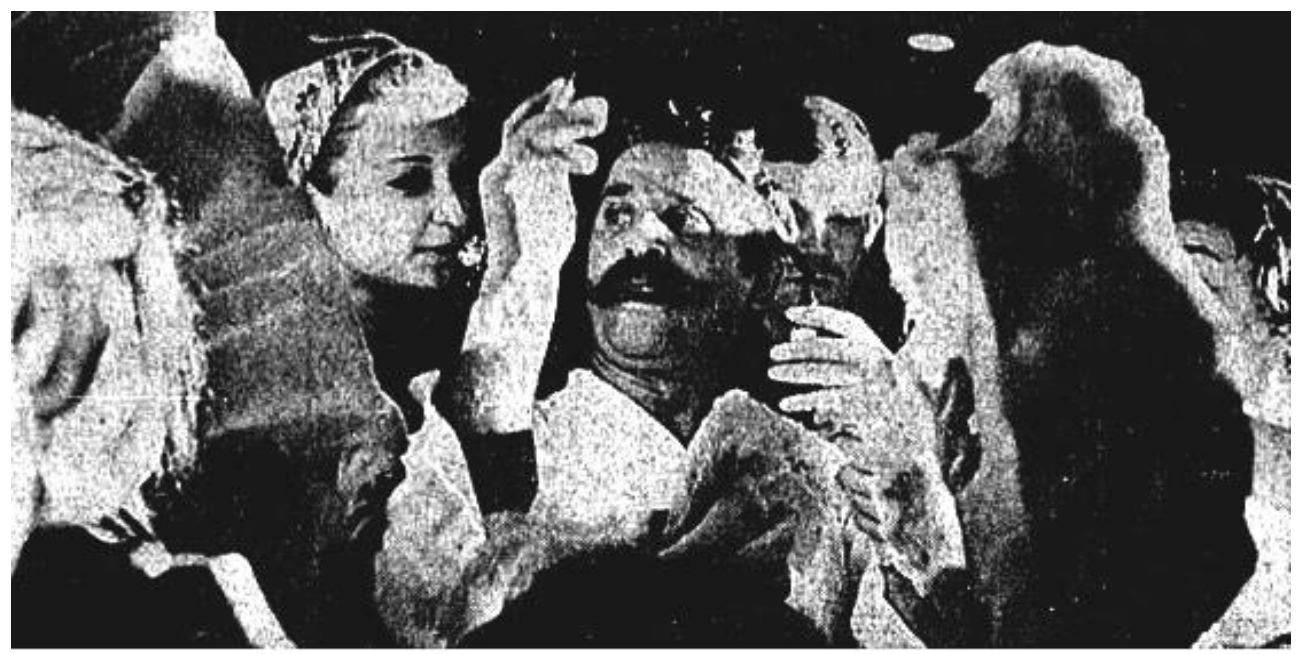

“A 'expansão' inicial de César foi estraçalhada, como queria o pintor, mas o público avançou para êle durante longo tempo com pedaços para autógrafos".

Jornal Correio da Manbã, 07 de outubro de 1967, 1ª́ página.

com suas esculturas criadas a partir do uso de máquinas de compressão de carros descartados em ferros velhos. Ao chegar ao Brasil para sua segunda participação, aí sim na IX Bienal, César começava a experimentar com um novo material: o poliuretano expandido, com o qual o artista fez formas em grandes formatos" [...] (MAGALHÃES, 2015, p. 15). 
Mário Pedrosa acompanhou o evento e apresentou o artista para o público antes de iniciada a experiência. Com o propósito de possibilitar a participação do público, todos os presentes foram convidados a intervir no processo criativo, que foi descrito detalhadamente pela imprensa:

[...] Auxiliado por alguns operários, o artista abriu as latas de plástico que despejou em outro vasilhame, deixando ver sua côr amarelo-ouro. Em seguida, com uma espécie de batedor de grandes proporções, ligado à eletricidade, bateu o líquido plástico até atingir 80 graus. Ao chegar ao ponto desejado, sempre auxiliado, César virou o tubo deixando correr sôbre o solo, recoberto por um tecido plástico, o conteúdo aquecido, recuando no ponto inicial, sob controle de quantidade, até esvaziar [...] Uns gostaram, outros ficaram frustrados. Outros simplesmente não entenderam. Começou então a reação táctil. Todos queriam tocar. De início, timidamente. Depois César puxou Restany para cima da peço que começou a se romper. E aconteceu a grande loucura, a grande participação: o público todo pulou para cima da forma, arrancando pedaços, numa alegria de recreio de colégio [...] (Jornal Correio da Manhã, 07 de outubro de $1967,1^{a}$ página).

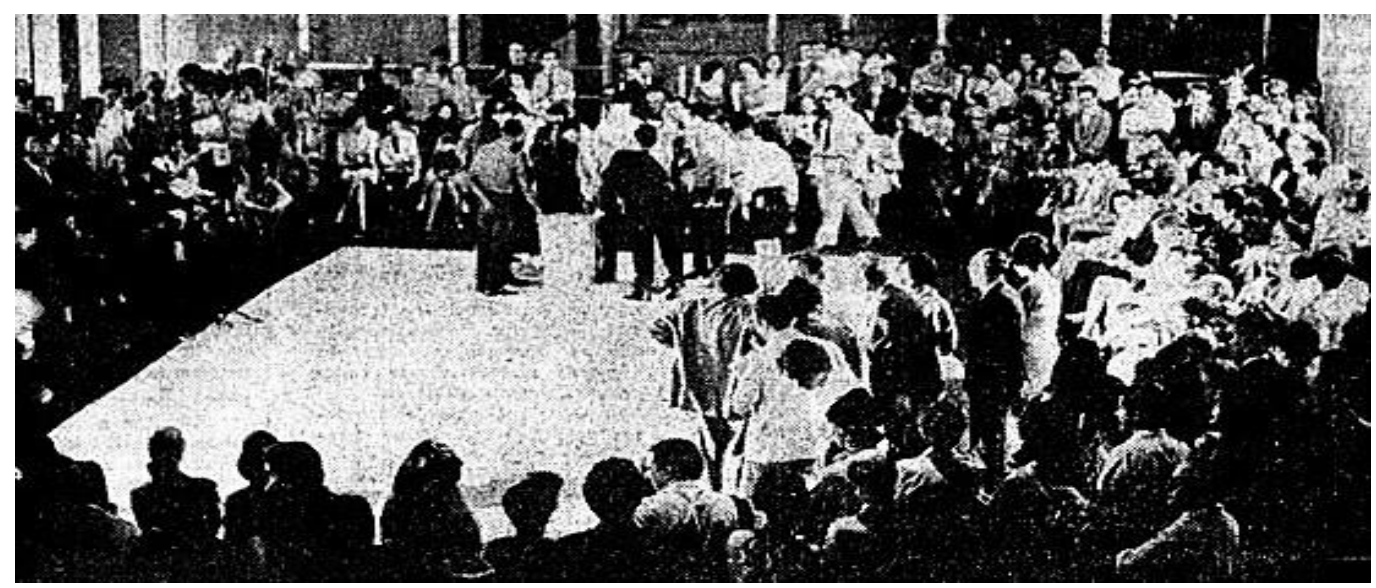

"O público ocupou literalmente tôda a área do local onde César fêz sua expansão".

Jornal Correio da Manhã, 07 de outubro de 1967, 1ª página.

A pluralidade de proposições estéticas era alvo de considerações na crítica de arte. Das várias tendências artísticas no final da década de 1960, a pop art tornava-se central nas discussões realizadas. Na análise do campo artístico, Mário Pedrosa apresentava o panorama das artes plásticas, opinava, posicionava-se e questionava a função social da arte. Desta forma, afirmou:

[...] A arte de hoje em dia, faça-se aqui ou alhures, em Paris, Nova York ou Campina Grande [...] é extrovertida, desabusada, antiestética. Quer dizer, teme ser acusada de hermética, aristocrática, não comunicativa, alienada. Terrivelmente concorrenciada pelos meios de comunicação de massa, entre os quais o cinema - e sua variante, a televisão - detém o primeiro lugar, a pobre pintura, a pobre escultura quiseram também vir ao grande público. [....] As artes plásticas de hoje por isso mesmo sacrificam os velhos valores abstratos e formais intrínsecos à mera vontade de informar, de comunicar. [...] Mas o pop, em países como o nosso, não pode ter a mesma finalidade senão em artistas a que só atrai a novidade dos grandes meios a empregar [...] Tornam-se virtuoses, preciosos, perfeitamente em dia com os processos em moda, mas o que inventam é detalhe, o que acrescentam é capricho. Acabam meros artistas, isto é, fazendo no fundo arte pela arte, ou antiarte pela antiarte. Ou são mundanos, ou são no máximo dadaístas arcaizantes [...] (PEDROSA, Mário. "Do pop ao sertanejo Dias". Jornal Correio da Manbã, 29 de outubro de $1967,4^{\circ}$ Caderno, p. 3).

Mário Pedrosa, além de dirigir críticas àqueles que faziam "arte pela arte", que cediam aos 
apelos publicitários e modismos, distinguia os artistas que, na sua opinião, utilizavam suas obras para fazer a denúncia dos problemas sociais e, contribuíam, consequentemente, para a mudança social e a valorização da arte. No texto de sua coluna, citava dois exemplos de artistas, nomeadamente: Rubens Gerchman e Antônio Dias:

[...] Nem todos porém são assim, pois quando a linguagem ou os veículos do pop os tomam, há neles uma ingenuidade nativa, uma temática essencial, um modo de ser incoercível, que não lhes dão a gratuidade necessária para abraçar, com vivacidade, brilho e naturalidade qualquer causa publicitária. É que, por exemplo, jovens como um Gerchman, com sua denúncia permanente das misérias de sua cidade nativa e seu amor extrovertido aos botecos à luz neón, onde o povo frequenta, ou um Antônio Dias, não fazem coisas visando à satisfação publicitária do consumismo pelo consumismo. A diferença deles, popistas do subdesenvolvimento é que escolhem para quem produzir. [...] Antônio Dias [...] já ocupa na arte jovem brasileira um lugar à parte e na linha de frente internacional tem seu posto de combate [...] Não veio Dias com suas imagens propor qualquer solução, antes reavivar constantemente nêle, em nós, nos outros - a perplexidade do mundo e o inconformismo da vida (PEDROSA, Mário. "Do pop americano ao sertanejo Dias”. Jornal Correio da Manhã, 29 de outubro de 1967, 4 Caderno, p. 3).

Em 14 de dezembro de 1967, foi inaugurado o IV Salão de Arte Moderna de Brasília, no Distrito Federal, organizado pela Fundação Cultural do Distrito Federal. A exposição, coletiva, reunia obras de artistas nacionais - de vários estados - e estrangeiros. O júri foi composto por membros da Associação Internacional de Críticos de Arte, sendo: Clarival do Prado Valadares, Frederico Morais, Mário Barata, Mário Pedrosa e Valter Zanini, que conferiu a maior premiação ao artista pernambucano, João Câmara Filho que recebeu NCr\$5.000,00 e, ao artista Hélio Oiticica, foi concedida uma referência especial. Sobre o evento, em sua coluna, Mário Pedrosa relatou o panorama do salão, afirmando que, as obras "sintetizavam a nação brasileira", revelavam a pluralidade de influências e proposições estéticas e comparou as obras dos artistas:

[...] No IV salão de arte de Brasília, que ora se abre, todas essas linhas se encontram. Não se fundem porque mostram, ao contrário, as divergências que se cruzam, as orientações que se cortam, movimentos que partem de pontos diferentes, mostrando ângulos diferentes, tempos diferentes. Em tempos diferentes, um dos pólos do salão e de maior impacto, é Pernambuco, com João Câmara Filho e Anchises de Azevedo; no pólo oposto está Hélio Oiticica, do Rio [...] Foi do contraste ou do contato dêsses pólos que nasceu, nos julgadores do salão, a consciência ou a imagem visível da "perspectiva de Brasília" [...] (PEDROSA, Mário. "Perspectiva de Brasília". Jornal Correio da Manhã, 17 de dezembro de 1967, 4 Caderno, p.3).

Frederico Morais destacou em sua coluna, a polêmica que envolveu o evento, quando o artista Nélson Leirner, de forma inusitada e provocativa, questionou o júri sobre aceitação de sua obra (objeto), colocando em evidência a questão: “o que é arte?”, provocando os críticos a justificar os critérios estabelecidos, causando, portanto, constrangimento e ampliando o debate:

[...] Os artistas de vanguarda da paulicéia (cada vez mais desvairada) andam muito ativos, agitados, provocadores. Trabalhando de preferência em equipe, têm participado ativamente dos salões, bienais, dos debates, e por onde passam deixam sua marca. Ainda recentemente no IV Salão de Arte Moderna, de Brasília, marcaram vários tentos, com uma participação por excelência polêmica. No momento, debatem a crise da AIAP (Associação Internacional de Artistas Plásticos, atualmente com sede em SP). Pouco antes, Nélson Leiner vai aos jornais perguntar ao júri de Brasília por que foi aceito [...] (MORAIS, Frederico. Jornal Diário de Notícias, 16 de janeiro de 1968, $2^{\mathrm{a}}$ seção, p.3). 
Nélson Leirner, que foi aceito na categoria desenho e objeto, enviou ao salão, a obra intitulada Porco com presunto, que se tratava de "um avantajado suíno empalhado com um presunto amarrado ao pescoço, dentro de engradado de madeira" (LOPES, 2016, p. 38). A atitude surpreendente e provocativa de Leirner, ampliava o debate sobre a concepção de arte e a estrutura dos espaços privilegiados: salões, bienais e outros, que mantinham a prática de seleção e premiação das obras de arte. Após o aceite da proposta enviada, o artista enviou carta aberta ao Jornal da Tarde (SP) solicitando ao júri esclarecimentos sobre os critérios estabelecidos para a seleção da obra. O artista argumentava que, sua intervenção na obra constituiu apenas em comprar o porco empalhado de um taxidermista. $\mathrm{O}$ episódio agitou o cenário artístico e a polêmica repercutia na imprensa. Sobre a atitude de Leirner argumentou-se:

[...] é inegável também que brincadeira de Leirner provocou um pequeno choque em tôda a nossa área de criação excêntrica, mais talvez do que a soma de tanta crítica que assume a coragem de defender o caos, seja como fôr e em que termos fôr, mas que não tem o cuidado de delatar a mistificação que a idéia (ainda que saudável) de agressão e provocação tem carregado consigo. Na medida em que o porco provoca êste tremor de terra, encontra sua validade. Mas uma validade que não vem autorizar seus propósitos, mas que convida a uma pausa para a meditação [...] a ironia e o deboche do artista Nélson Leirner são certamente contra os critérios delirantes que a crise da figuração nos agraciou. Neste sentido o porco é um marco importante [...] (AYALA, Walmir. "O porco e a bolação". Jornal do Brasil, 24 de janeiro de 1968, Caderno B, p.2).

A resposta solicitada por Leirner foi dada. Mário Pedrosa, que presidiu o júri do salão de Brasília, respondeu a provocação de Leirner e "esclareceu” os critérios estabelecidos para a seleção da obra (o porco). Em texto amplo, discorreu sobre as transformações na História da Arte, a função do crítico e argumentava que a atitude do artista justificava a seleção da obra:

[...] vem um jovem artista paulista de talento, numa família aliás de artista, para interpelar o júri do salão de Brasília, em carta publicada em jornal, sôbre o critério que o levou a aceitar sua "obra”, Porco Empalhado, que mandou com outra um cêpo de madeira [um tronco de árvore na qual foi presa uma cadeira de madeira], sob a designação genérica algo escolástica de "matéria e forma". Esperava Nelson Leirner que o júri a tivesse recusado? Por que não tinha valor plástico? Por que não era uma obra de arte? Por que não fora "criada" ou não tinha originalidade? Mas se se trata de um "porco empalhado", alguém o empalhou. Empalhar animais é uma arte reconhecida e apreciada, a taxedermia. É também Nelson perito nela? Mas se êle apenas comprou o porco empalhado engradado e mandou a Brasília, a obra cai na categoria dos ready made à la Duchamp. [...] Ignoro se pelas leis de nosso fisco, aquêle produto, o porco empalhado, (aliás, com valor de venda inscrito) devia pagar alguma taxa. Também havia a considerar que nenhum de nós, membros do júri, tinha qualquer autoridade oficial para decidir sôbre a natureza fiscal do objeto ou mesmo qual a natureza que Leirner emprestara mentalmente à obra mandada a Brasília. Tinha, porém, o júri toda autoridade para aceitá-la no salão uma vez que o porco empalhado havia de ser para êle consequência de todo um comportamento estético e moral do artista. $\mathrm{Na}$ arte pós-moderna, a idéia, a atitude por trás do artista é decisiva (PEDROSA, Mário. "Do Porco Espalhado [sic], ou os critérios da crítica". Jornal Correio da Manbã, 11 de fevereiro de 1968, $4^{\circ}$ Caderno, p. 4 - grifos originais do texto).

Outro jurado do salão, Frederico Morais, também, respondeu. Afirmando ter enviado resposta à Nélson Leirner por carta, destacou em sua coluna, alguns trechos, corroborando a justificativa apresentada por Mário Pedrosa, que a atitude provocativa do artista foi determinante para ter sua obra selecionada. E, respondendo à questão “o que é arte?”, que a provocação do artista 
fazia, afirmou: "Tudo é válido para mim, tudo é passível de se transformar em arte: a vida, o viver, o próprio homem, e até o porco de Leirner". No texto, ainda, devolvia à Leirner questionamentos:

[...] Vou à resposta. A arte é, e sempre foi provocação. “A função da arte em relação à sociedade resulta clara: expressar a qualquer preço o que se oculta atrás do muro". "O artista é o que arranca o véu". [...] "Ora, provocar é dar um não, é propor um anti. É questionar. O que fizeram os artistas do Dada? Uma arte do não, antiarte". [...] "E não foi também êsse o seu comportamento ao mandar publicar no "Jornal da Tarde" a fotografia de seu "porco empalhado e enjaulado" e saber porque foi aceito? Ah! O porco de Leirner. O júri não aceitou o porco, tal como insinua no jornal. Considerou uma proposição digna de exame e interesse, ainda que, no título equivocada. Tanto que seu envio não constou apenas de uma obra, mas de duas, ambas abordando o mesmo problema. Não se trata, portanto, para o júri, do porco ou do tronco, mas de uma relação entre produtos e derivados, ou do porco e do pernil, do tronco e da cadeira. Ora, no IV Salão de Brasília deu outro nome às obras "Matéria e Forma", título muito mais comprometido com problemas de estética. Afinal, por que matéria e forma, se tudo é forma, se nada existe sem forma, mesmo o informe?” [...] À crítica de arte aberta, não interessa a obra em si, ela não julga mais, academicamente, os chamados valores plásticos, as qualidades artesanais. A esta crítica interessa o problema, a proposição (daí se falar de uma arte proposicional) e como ela foi resolvida [...] Aí estão as razões por que aceitei as duas obras no IV Salão de arte moderna de Brasília. Agora, se me permite, pergunto a você: por que só colocou a questão nos jornais, depois que seu trabalho foi aceito? E mais, se não fosse aceito seu porco, faria a pergunta no sentido inverno [sic] Antecipo minha resposta: seu porco foi cortado pelos mesmos motivos pelos quais o aceitei" (MORAIS, Frederico. "Como julgar uma obra de arte: O porco de Leirner”. Jornal Diário de Notícias, 14 de janeiro de 1986, $2^{\mathrm{a}}$ Seção, p. 3).

"Os textos de Frederico Morais, escritos em resposta ao happening de Nelson Leirner, evidenciam tanto um empenho de renovação da crítica de arte como o reconhecimento de que os antigos critérios não acompanhavam as transformações na produção artística da época" (TAGA, 2018, p. 88).

E, além da polêmica estabelecida, o IV Salão de Arte Moderna de Brasília, foi alvo de censura. Obras dos artistas Rubens Gerchman, Cláudio Tozzi e José Roberto Aguilar, que faziam referência ao líder guerrilheiro Ernesto Che Guevara, morto em 09 de outubro de 1967, pelo exército boliviano, foram retiradas do salão, por agentes do Departamento de Ordem e Política Social - DOPS -, consideradas "subversivas". A ação repercutiu na imprensa:

[...] Agentes do DOPS estiveram ontem por duas vezes seguidas no IV Salão de Arte Moderna de Brasília no Teatro Nacional, a fim de retirar os painéis Um Bilhão de Dólares e Só, de Rubens Guerchman [sic], Vivo ou Morto, de Claúdio Tozzi, e Êle, de José Roberto Aguilar, todos sôbre Ernesto Che Guevara, e que teriam deixado inconformados alguns setores militares [...] (Jornal do Brasil, 22 de dezembro de 1967, $1^{\text {a }}$ página). 


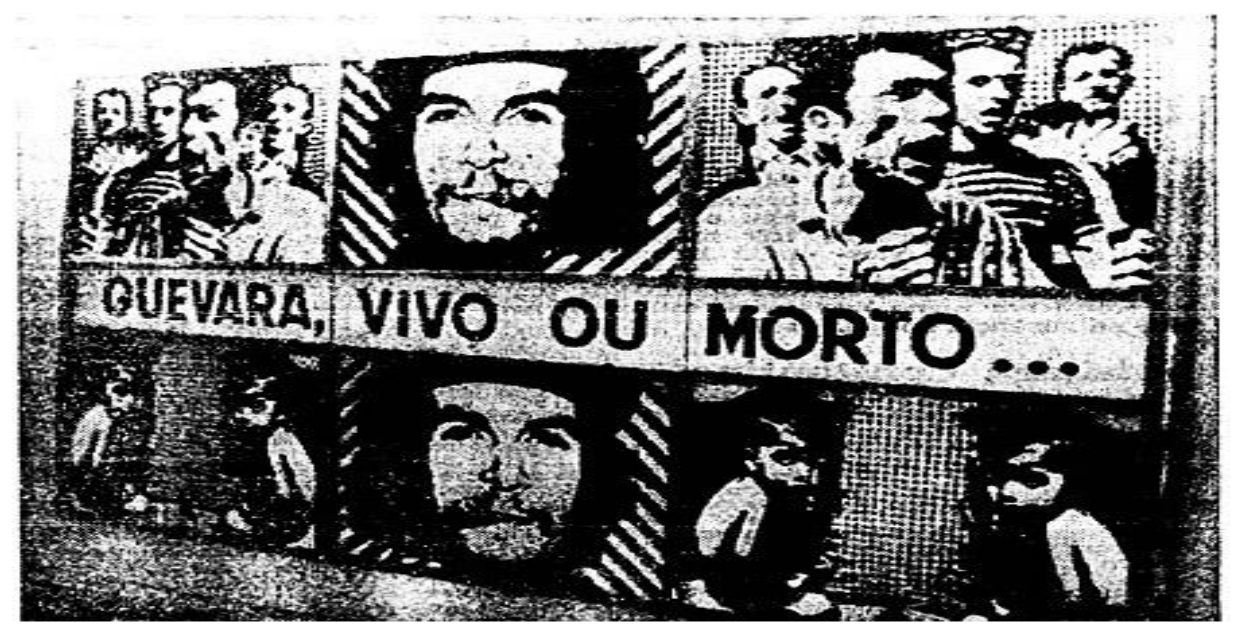

"Este painel de autoria de Cláudio Tozzi desagradou a alguns militares".

Jornal do Brasil, 22 de dezembro de $1967-1^{\circ}$ Caderno, p. 10.

[...] A primeira vista, Guevara, de Claúdio Tozzi, surge como um retrato do conhecido guerrilheiro latino-americano. Num segundo momento, aos olhos mais treinados, a obra traz referências diretas ao sucesso da pop-art na Bienal de São Paulo de 1967. E, finalmente, num outro nível de avaliação, a pintura de Tozzi afasta-se da pop norte-americana tanto pelas declarações do próprio artista (que ingenuamente reduzia a pop americana a um movimento acrítico e despolitizado), quanto pela dimensão da própria obra [...] (FREITAS, 2004, p.75).

A polêmica sobre a questão do "porco empalhado" e o questionamento de Nelson Leirner ao júri do IV Salão de Arte Moderna de Brasília, continuou repercutindo. Mobilizou diversos críticos, cumprindo, portanto, o intuito do artista de provocar reações e discussões sobre a arte. Sobre o propósito da criação e atitude tomada, o próprio artista explicou:

[...] Como na natureza, o porco também cumpriu seu papel no Salão de Brasília. Quando o suíno ainda em meu atelier, apesar de empalhado, ganhava vida ao ser engradado ao mesmo tempo que do lado de fora ficava pendurado um presunto, notei que o espaço entre o animal e o produto industrializado, caracterizava todo um processo social aonde o espectador poderia tomar consciências de sua condição. Logo não houve provocação no sentido de deboche, como muitos o querem, mais [sic] sim uma tentativa de provocar uma conscientização da realidade do aqui-agora [...] (MORAIS, Frederico. "Porco e aposentadoria", Jornal Diário de Notícias, 04 de fevereiro de 1968, $2^{\mathrm{a}}$ Seção, p. 3).

Justificando, portanto, a sua atitude, Nélson Leirner recusava a acusação de deboche dirigida ao júri e da ação inconsequente no salão de Brasília, afirmando a reflexão e preocupação com a denúncia e a tentativa de conscientização através da arte. O artista, ainda, lamentava que o único a tratar com seriedade e compreender sua proposição, fora Frederico Morais, mesmo que este revelasse discordância de alguns de seus pontos de vista no processo criativo. A provocação de Leirner, portanto, ampliava o debate sobre a arte brasileira e a vanguarda, bem como mobilizava os críticos a apresentarem suas opiniões sobre o estatuto da arte, papel do artista e questões de estética.

\section{Considerações finais}

A análise das colunas assinadas por - Frederico Morais, Harry Laus e Mário Pedrosa -, possibilita acompanhar o panorama das artes plásticas, no Brasil e no mundo, durante a década de 
1960. Os textos dos referidos colunistas, apresentam a trajetória dos movimentos estéticos na História da Arte, a análise do cenário internacional e nacional, evidenciando o diálogo estabelecido e as influências recebidas e apropriadas. Os críticos de arte apresentam a pluralidade de proposições nos respectivos eventos, selecionados para este estudo, tecem suas considerações sobre as obras e posicionam-se sobre as tendências artísticas. Comparando as criações estéticas, dão ênfase as produções de Antônio Dias, Lígia Clark, Hélio Oiticica e Rubens Gerchman como os artistas de maior relevância nas artes plásticas no período. Considerados inovadores e sintonizados com a realidade social, suas obras foram alvos privilegiados de discussão entre os críticos.

Os textos, também, evidenciam a importância que a arte ocupava no debate durante os anos 1960. Eventos com a participação de artistas nacionais e estrangeiros foram espaços privilegiados para a apresentação das experiências e pesquisas nas artes plásticas. E, mesmo com a busca de deslocar o debate para outros territórios, além de São Paulo e Rio de Janeiro, o MAM/RJ, destacou-se como o "epicentro" no campo artístico da década de 1960. Arte, antiarte, função social, papel do artista e participação ativa do público, formulavam as principais questões, que os críticos privilegiaram em suas colunas, apresentando um ambiente agitado e de intensa atividade dos artistas.

As opiniões dos críticos divergiam em torno das temáticas, contudo, em comum, apresentavam a defesa da liberdade no processo criativo e a recusa de modos esquemáticos. $\mathrm{O}$ tom dos textos, também, permite considerar a defesa enfática e os posicionamentos evidentes de Frederico Morais e Mário Pedrosa. Já Harry Laus limitava-se a narrar os eventos e a trajetória dos artistas, sem apresentar a "defesa" de determinadas criações.

Por fim, nota-se que, no contexto autoritário vivido no Brasil durante a década de 1960 e, consequentemente, as medidas de cerceamento das liberdades implantadas, reivindicar o livre processo criativo, recusar os modelos esquemáticos, questionar práticas convencionais e o academicismo era, também, um ato político e de oposição do estado autoritário.

\section{Referências}

ABREU, Simone Rocha de. Lutas e tensões nas obras de Rubens Gerchman. Revista USP. São Paulo, n.116, p. 60-80. Janeiro/fevereiro/março, 2018.

AMARAL, Aracy Abreu. Arte para quê?: a preocupação social na arte brasileira, 1930-1970. São Paulo: Nobel, 1984.

BARROS, José D’Assunção. Mário Pedrosa e a crítica de arte no Brasil. ARS (São Paulo), 6 (11), 4060, 2008.

CAVALCANTI, Jardel Dias. Artes Plásticas: vanguarda e participação política (Brasil anos 60 e 70). Tese (Doutorado em História). Instituto de Filosofia e Ciências Humanas da Universidade Estadual de Campinas. Campinas, SP, 2005.

COUTO, Maria de Fátima Morethy. A arte de vanguarda e a crítica de arte no Brasil (1950-1970). Revista do Centro de Pesquisa e Formação, n.9, novembro, 2019.

DUNN, Christopher. "Nós somos os propositores": vanguarda e contracultura no Brasil, 19641974. [Tradução Lília Gonçalves Magalhães Tavolaro]. Revista Art Cultura, Uberlândia, v.10, n.17, p. 143-158, jul.-dez., 2008.

FERNANDINO, Fabrício. (R) Evolução Frans Krajcberg, o poeta dos vestígios. Rev. UFMG, Belo Horizonte, v.21, n.1 e 2, p. 260-277, jan.dez., 2014.

FREITAS, Artur. Poéticas políticas: as artes plásticas entre o golpe de 64 e o Al-5. História: Questões 
\& Debates, Curitiba, n.40, p. 59-90, 2004.

LOPES, Almerinda da Silva. Apropriação e ironia na instalação "Vestidas de branco" de Nelson Leirner. Revista Estúdio, Artista sobre outras obras, 7 (14), p. 36-43, 2016.

MAGALHÃES, Ana. César Baldaccini. In: CHIARELLI, Tadeu (Org.) Acervo: Outras Abordagens. São Paulo: Museu de Arte Contemporânea da Universidade de São Paulo, 2015, vol. 2.

MALBRÁN, Florencia; “Dobles: Opinião 65 entre el pasado y el presente”. En Caiana. Revista de Historia del Arte y Cultura Visual del Centro Argentino de Investigadores de Arte (CAIA). $n^{\circ} 12$, Primeiro semestre, 2018, p. 18-25.

PALMEIRA, Marília. Opinião 65 - 50 anos depois. Revista Concinnitas, ano 16, volume 02, número 27, dezembro de 2015.

PALUMBO, Carmen. A Amazônia como lugar de conflito: o Naturalismo Integral de Pierre Restany. Dissertação (Mestrado em Estética e História da Arte). Universidade de São Paulo. São Paulo, 2018.

REIS, Paulo. Nova Objetividade Brasileira - posicionamentos da vanguarda. MODOS. Revista de História da Arte. Campinas, SP. v. 1, n.3, p. 98-114, set./dez., 2017.

SANT'ANNA, Sabrina Patracho. Musealização, crítica de arte e o exercício experimental da liberdade em Mario Pedrosa. Revista Est. Hist., Rio de Janeiro, vol. 24, n. 48, p. 385-404, julho-dezembro de 2011.

TAGA, Ricardo. Frederico Morais: crítica de arte e vanguarda no Brasil (1962-1972). Dissertação (Mestrado) apresentada ao Programa de Pós-Graduação em Arte, da Universidade de Brasília. Brasília, 2018.

TEJO, Cristiana Santiago. A gênese do campo da curadoria de arte no Brasil: Aracy Amaral, Frederico Morais, Walter Zanini. Tese (Doutorado em Sociologia) Universidade Federal de Pernambuco. Recife, 2017.

VIEIRA, Maria Aparecida Borges. Os papéis de Harry Laus: um perfil do crítico de arte no jornalismo brasileiro. Dissertação (Mestrado em Literatura Brasileira). Universidade Federal de Santa Catarina. Florianópolis, 2009.

Artigo recebido em: 26/05/2020

Artigo aceito em: 20/07/2020 